\title{
Disturbance, succession and stability: a ten year study of temporal variation of species composition after a catastrophic flood in the river Paraná, Argentina
}

\author{
E. A. Franceschi ${ }^{1}$, P. S. Torres ${ }^{1}$, D. E. Prado ${ }^{2}$ and J. P. Lewis ${ }^{3}$ \\ ${ }^{1}$ CIUNR and Cátedra de Ecología, Facultad de Ciencias Agrarias, Universidad Nacional de Rosario. \\ CC 14. 2123 Zavalla (S. Fe). Argentina. \\ ${ }^{2}$ CONICET and Cátedra de Botánica, Facultad de Ciencias Agrarias, Universidad Nacional de Rosario. \\ CC 14. 2123 Zavalla (S. Fe). Argentina. \\ ${ }^{3}$ CONICET and Cátedra de Ecología, Facultad de Ciencias Agrarias, Universidad Nacional de Rosario. \\ CC 14. 2123 Zavalla (S. Fe). Argentina.
}

Keywords: Diversity, Extraordinary events, Permanent plots, Regeneration succession, Riparian vegetation, Trajectories, Vegetation dynamics.

\begin{abstract}
The River Paraná is the second largest river of South America and its flood plain is covered by different kinds of forests and herbaceous vegetation. It is subject to an annual pulse of flooding; floods larger than the normal annual ones at irregular periods of few year and catastrophic extraordinary floods few times in a century. The last catastrophic flood was in 1983, followed by a short lived high flood in 1992. The catastrophic flood destroyed almost completely the herbaceous vegetation. Our hypotheses are, on the one hand, that the plant communities of this area will be restored rapidly, and on the other, that there will be a succession process which will produce a shift of communities so that, those on the higher part of the elevation gradient will encroach the ones at its lower part. We analyse, by means of the floristic composition, the effect of disturbance induced by catastrophic floods on the vegetation stability and dynamic processes, in an internal depression and pond of the riparian plant communities in an island of the River Paraná valley. The results strongly support the first hypothesis.
\end{abstract}

Nomenclature: Cabrera (1963-1970); Burkart (1969-1987)

\section{Introduction}

The River Paraná is the second largest river of South America. From its confluence with the River Paraguay, it runs from north to south between two tectonic scarps through a floodplain up to where it joins the River Uruguay and forms the River Plate which in fact is a large estuary (Iriondo 1972, Iriondo and Drago 1972). The Paraná river valley is subject to a yearly pulse of seasonal flooding, reaching its peak in autumn and the lowest water level in spring; every few years at irregular intervals there are major floods and few times in a century there are extraordinary catastrophic floods, such as the 1905 and 1983 ones, during which only the crown of the tallest trees emerge from the waters (Lewis et al. 1987).

On the river banks, the peripheral levees of the islands and sand bars there are different kinds of forests and shrublands, whereas inside and around the internal de- pressions of the islands there are several kinds of herbaceous communities. General surveys and descriptions of the River Paraná vegetation can be found in Morello (1949), Burkart (1957) and Franceschi and Lewis (1979). As to its floristical composition, it is related to the Misiones nucleus of Prado and Gibbs (1993), and the peculiar subtropical climate in which it thrives (Bonetto 1975). The forests and herbaceous communities in the River Paraná valley belong to the subtropical Paranaense phytogeographical province of Cabrera (1976). The dynamics of all these vegetation types are intensely influenced by the hydrological regime and the frequency and length of the floodings (Lewis and Franceschi 1979), of which the extraordinary ones destroy the herbaceous vegetation altogether and seriously affect the woody communities (Lewis et al. 1987), thus causing a high intensity disturbance at landscape level (van der Maarel 1993). 
The zonation of the herbaceous communities, arranged in concentric rings around a shallow lake at the center of the islands and following a slight elevation gradient, has been taken as an indication of successional sequence leading to a forested climax (Morello 1949, Burkart 1957). The community sequence consists of an internal ring of "canutillares" of rooted floating Graminae (mainly Panicum elephantipes and Echinochloa polystachya), followed by "verdolagales" of Ludwigia peploides, several "cataisales" of different species of the genus Polygonum, and in the outer ring the tall grasslands of Panicum prionitis ("paja de techar"). However, not all zonation should be taken as evidence of succession (Dansereau 1957); moreover, Lewis and Franceschi (1979) questioned the chance of the $P$. prionitis tall grasslands to develop into a forest.

The 1983 extraordinary catastrophic flood was the most important of the century (Bó and Malvárez 1999); it lasted for more than two years and wiped out all herbaceous vegetation of the flooding valley of the Paraná River (Lewis et al. 1987, Franceschi and Prado 1989). Subsequent floods reached a similar height but they were of far shorter duration, such as that in 1992 (Bó and Malvárez 1999). However, the $P$. prionitis tall grassland has been established to be very stable, since the initial floristic composition was restored quite rapidly (Franceschi and Lewis 1991). Thus, this community resulted to be resilient (sensu Westman 1978, Westman and O'Leary 1986) and persistent (Connell and Sousa 1983, Veblen 1992). This persistence of the populations of the different species, which did not become extinct during and after the floods, is achieved through the "propagule stage" (sensu Noble and Slatyer 1980), probably mainly of vegetative origin though fruits and seeds are not ruled out; such is the case of the $P$. prionitis tall grasslands (Franceschi and Lewis 1991).

There is a considerable body of research on disturbance in plant community ecology, particularly referring to northern hemisphere forest vegetation (Engelmark et al. 1993, Bergeron et al. 1998) and temperate grasslands (van der Maarel 1993). Different views and varying concepts of disturbance can be traced in the modern literature, sometimes with more emphasis on the patterns of succession (Grime 1979, Sousa 1984, Denslow 1985, Pickett and White 1985, Tilman 1985, Glenn-Lewin and van der Maarel 1992) than with respect to stability, a concept still undefined clearly (van der Maarel 1993). Despite that "there is a general feeling that disturbance and stability are closely interrelated" (van der Maarel 1993), it remains to be seen how these two concepts may be linked. Van der Maarel's (op. cit.) maintains that stability is only possible as a result of disturbance ("Disturbance FOR Stability"), particularly bearing in mind temperate grasslands and boreal forests.

In the present contribution we analyse, by means of the floristic composition, the effect of disturbance induced by catastrophic floods on the vegetation stability and dynamic processes, in an internal depression and pond of the riparian plant communities in an island of the River Paraná valley. Our hypotheses are that 1) the plant communities of this area will be restored rapidly and 2) there will be a succession process which will produce a shift of communities so that those on the higher part of the elevation gradient will encroach the ones at its lower part.

\section{Methods}

Study site and sampling

The study site is on the island Campo Rico, which is part of the "El Rico" Provincial Reserve of the flood plain of the River Paraná valley (Franceschi et al. 1985), placed between $32^{\circ} 10^{\prime}$ and $32^{\circ} 25^{\prime} \mathrm{S}$, and $60^{\circ} 40^{\prime}$ and $60^{\circ} 45^{\prime} \mathrm{W}$, Santa Fe Province, Argentina (Fig. 1). Accessibility to this site is difficult in normal times and impossible during major floods.

On March 1986, thirty 2.5 by $2.5 \mathrm{~m}$ permanent plots were laid at regular intervals along a $600 \mathrm{~m}$ long transect, from the forested levee down to the edge of the central lake of the island. Relative topographic elevation was determined with an optical level. In each plot floristic lists were made and the abundance-cover of species was estimated by means of Braun-Blanquet's (1979) combined scale. The choice of the site was based on the authors' pre-

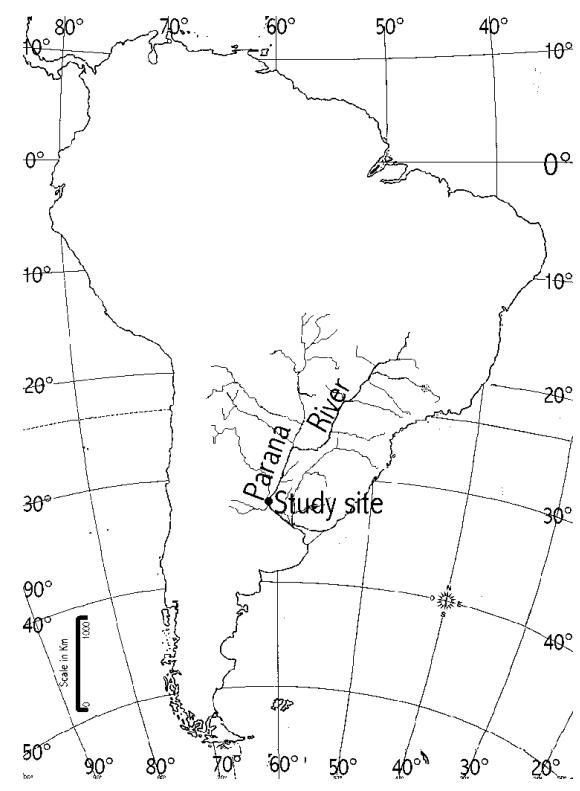

Figure 1. Geographic localization of the study site. 
vious knowledge of the Reserve and island whose vegetation had been mapped and analysed shortly before (Franceschi et al. 1985). The first vegetation sampling for all quadrats was performed in autumn 1986 (Franceschi and Prado 1989), and from this time onwards the visits to the area and vegetation sampling were conducted during successive springs until 1996, with the exception of the years 1990 and 1992 when major floodings prevented the access to the island. Thus, nine annual data series are available.

Shortly after data records were taken in 1988, an apparently spontaneous fire affected most of the Reserve and the transect area; this was followed by a relatively early major flood in 1989. As an environmental reference of the hydrological conditions during the yearly period of data gathering, the highest annual level is provided and the average daily height of the river at the Diamante hydrological station was calculated for the 120 days before the date of data recording (Fig. 2).

\section{Data analysis}

A data matrix was built up of 270 vegetation sample units and 65 species; species appearing in only one relevé were omitted since they only add noise to the analysis (Gauch 1982). Also, the free floating plant species were omitted because drift made their record unreliable. Classification of the sample units was performed employing the sum of squares method, with Euclidean distance as dissimilarity measure (Wildi and Orlóci 1990). Sample units and species were also ordered with the reciprocal averaging method (McCune and Mefford 1999). In order to detect any possible successional development, the individual trajectory for each plot along the whole period was determined (Austin 1977). Quadratic regression analysis between Axis I of the numerical analysis and relative topographic elevation was performed. Shannon and Weaver diversity index (McCune and Mefford 1999) was calculated and averaged for each year, differences be- tween years were compared with the Friedman test (Siegel 1980, Hollander and Wolfe 1973).

To facilitate the comparison with the pre-catastrophic flood situation, sample units recorded during the 1981 survey (Franceschi et al. 1985) corresponding to equivalent communities to those classified here, were compiled in each community. Thus, five artificial relevés were allocated through an identification method (Wildi and Orlóci 1990) to the groups produced by classification.

\section{Results}

The classification of sample units produced three main groups: Group 1 is the more homogeneous and welldefined, characterized by the abundance of the dominant tall grass $P$. prionitis. The less homogeneous Groups 2 and 3 are more closely related to each other than to Group 1 , and they are characterized by the dominance and abundance of Polygonum acuminatum and L. peploides, respectively (Fig. 3). The pre-catastrophic flood artificial relevés were assimilated in the classification analysis by their corresponding post-disturbance groups without any trouble. Taking these groups into account, the vegetation types recorded for each year in all permanent plots are summarized in Table 1. Thus, the 30 permanent plots can be classified as follows: a) five plots whose vegetation type has not changed whatsoever throughout the analysed period, of which four correspond to $P$. prionitis tall grasslands and one is a "verdolagal" of $L$. peploides; b) five plots which have suffered different changes but all ended in the more hygrophilous community of $L$. peploides; c) 16 plots (over $53 \%$ of all plots) that remained stable during the first three years with a turning point from 1989 onwards; most of them (14 plots) belonged to Group 2 (P.acuminatum) at the beginning of the study, but generally (13 plots) ended in the related Group 3 (L. peploides). Finally, d) with the last four plots, all of which started and ended in Group 3, though they started fluctuating between Groups 3 and 2 in 1989 after the fire followed by a relatively more severe flood.

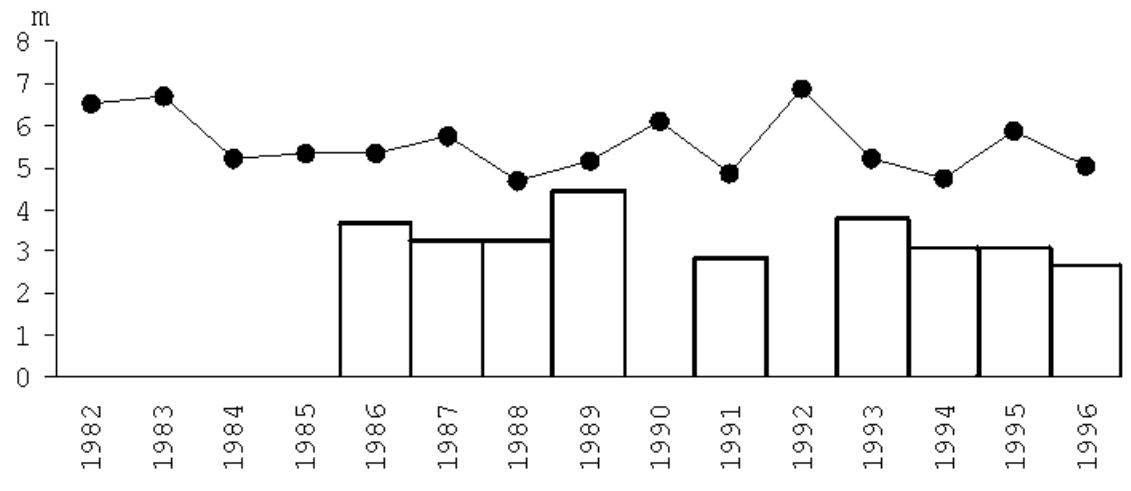

Figure 2. Annual maxima of water height (dots) and average height of 120 days before vegetation data records (columns). Data from Departamento Distrito Parana Medio (Diamante). 
Table 1. Groupings of the sample units in successive years. Scores indicate the group produced by sum of squares method to which each sample unit belongs in successive years. Broken line indicates the permanence of the initial vegetation.

\begin{tabular}{|c|c|c|c|c|c|c|c|c|c|c|}
\hline Plats & 1986 & 1987 & 1988 & 1989 & 1991 & 1993 & 1994 & 1995 & 1996 & \\
\hline 2 & 1 & 1 & 1 & 1 & 1 & 1 & 1 & 1 & 1 & \\
\hline 6 & 1 & 1 & 1 & 1 & 1 & 1 & 1 & 1 & 1 & \\
\hline 7 & 1 & 1 & 1 & 1 & 1 & 1 & 1 & 1 & 1 & $a$ \\
\hline 12 & 1 & 1 & 1 & 1 & 1 & 1 & 1 & 1 & 1 & \\
\hline 1 & 3 & 3 & 3 & 3 & 3 & 3 & 3 & 3 & 3 & \\
\hline 8 & 1 & 1 & 1 & 1 & 1 & 1 & 1 & 1 & 3 & \\
\hline 27 & 2 & 2 & 2 & 2 & 2 & 2 & 2 & 3 & 3 & \\
\hline 22 & 3 & 3 & 3 & 3 & 3 & 3 & 2 & 3 & 3 & $b$ \\
\hline 25 & 3 & 3 & 3 & 3 & 3 & 2 & 2 & 2 & 3 & \\
\hline 4 & 1 & 1 & 1 & 1 & 3 & 1 & 1 & 3 & 3 & \\
\hline 13 & 2 & 2 & 2 & 3 & 3 & 3 & 3 & 3 & 3 & \\
\hline 21 & 2 & 2 & 2 & 3 & 3 & 3 & 3 & 3 & 3 & \\
\hline 11 & 2 & 2 & 2 & 3 & 3 & 3 & 3 & 3 & 3 & \\
\hline 16 & 2 & 2 & 2 & 1 & 1 & 1 & 1 & 1 & 1 & \\
\hline 5 & 1 & 1 & 1 & 3 & 1 & 3 & 3 & 3 & 3 & \\
\hline 17 & 2 & 2 & 2 & 3 & 3 & 3 & 2 & 3 & 3 & \\
\hline 18 & 2 & 2 & 2 & 3 & 3 & 2 & 2 & 3 & 3 & \\
\hline 19 & 2 & 2 & 2 & 3 & 3 & 2 & 3 & 3 & 3 & c \\
\hline 15 & 2 & 2 & 2 & 3 & 2 & 2 & 2 & 3 & 3 & \\
\hline 3 & 2 & 2 & 2 & 3 & 3 & 2 & 2 & 2 & 2 & \\
\hline 9 & 2 & 2 & 2 & 3 & 3 & 2 & 2 & 3 & 3 & \\
\hline 10 & 2 & 2 & 2 & 3 & 2 & 2 & 2 & 2 & 2 & \\
\hline 14 & 2 & 2 & 2 & 3 & 3 & 3 & 2 & 3 & 3 & \\
\hline 28 & 2 & 2 & 2 & 3 & 2 & 3 & 2 & 3 & 3 & \\
\hline 23 & 2 & 2 & 2 & 3 & 3 & 2 & 2 & 3 & 3 & \\
\hline 26 & 3 & 3 & 3 & 2 & 2 & 3 & 3 & 3 & 3 & \\
\hline 20 & 3 & 3 & 2 & 3 & 3 & 2 & 2 & 3 & 3 & \\
\hline 29 & 3 & 3 & 2 & 3 & 3 & 2 & 3 & 3 & 3 & d \\
\hline 24 & 3 & 2 & 2 & 3 & 3 & 2 & 2 & 2 & 3 & \\
\hline 30 & 3 & 2 & 2 & 2 & 2 & 2 & 2 & 3 & 3 & \\
\hline
\end{tabular}

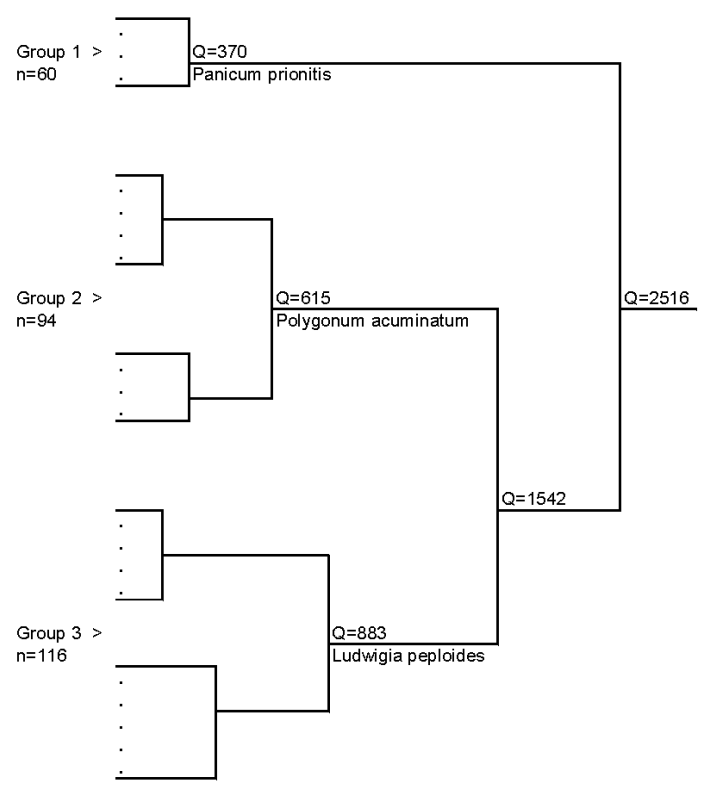

Figure 3. Dendrogram of the vegetation sample units obtained by the sum of squares agglomeration method (Q: value of sum of squares).
The ordination of the 270 sample units (Fig. 4a) produced a considerable dispersion along Axis I but no clusters are formed whatsoever, while Axis II only disperses a few sample units $(5 \%)$ of the negative extreme of Axis I. They are the 1986 sample units of plots 21 to 30, except for plot 27, and also the 1987/88/89 sample units of plot 29 (topographically the lowest one and the more susceptible to flooding). On the other hand, the ordination of the 65 species (Fig. 4b) shows clearly that the more hygrophilous ones tend to concentrate towards the negative extreme of Axis I, whereas the more mesophilous species are located in the positive end of the same axis, therefore suggesting that this Axis I is related to a notorious humidity gradient. Moreover, the correlation between Axis I of the numerical analysis and relative topographic elevation of each permanent plot resulted to be positive (Fig. 5), with the higher plots being therefore placed in the positive extreme of Axis I and the lower plots (more floodable and spatially closer to the central lake) towards its negative extreme.

The temporal trajectories of each permanent plot show very restricted movements throughout the analysed period, mostly concentrated in small segments of Axis I (Fig. 6a,b) without any directionality at all. In most of the plots, the sample units of the different years are closely grouped, except for the more separated 1986 sample units of plots 21, 22, 26, 28 and 30, and the 1986 and 1989 sample units of plot 29 (Fig. 6b). Diversity (Fig. 7a) and floristic richness (Fig. 7b) are relatively stable, showing scarce variation throughout the analysed period but with moderate peaks in 1986 and 1991 after major infrequent disturbances, however, differences between years are not significant $(\mathrm{p}<0.05)$ at all and equitability (Fig. 7c) varies even less and differences between years are also not significant $(\mathrm{p}<0.05)$.

\section{Discussion}

The floristic composition at a particular study site reflects both the predominant present environmental conditions and the historical events, and probably the best way to detect successional tendencies consists in following the variation of the floristic composition through time (Philipi et al. 1998). The deployment and survey of permanent plots allow for a better evaluation of the floristic changes involved, given that this method reduces the confusion between small scale temporal and spatial variations (Bakker et al. 1996). If relevant successional changes had occurred at a particular site, the ordination methods of vegetation analysis should reveal an association between time and one of the first three axes; however, such link was not found in the present study. On the con- 
trary, the significant correlation found between Axis I and both the topographical elevation (Fig. 5) and the species sequence according to their degree of hygrophily (Fig. $4 b$ ), permits a confident assignment of this axis to an environmental gradient of humidity.

It has been stated that time and space are related in vegetation dynamics (Glenn-Lewin and van der Maarel 1992), and that the shaping forces for vegetation change over large areas are generally the same as those generating change over long time spans (Austin 1981, Delcourt et al. 1983, Falinski 1988). In this sense it is interesting to note that the aforementioned gradient of humidity has been identified as the major environmental factor controlling the vegetation variation after the analysis of the first year data (Franceschi and Prado 1989). A decade of yearly and major floods and a combined double disturbance (the
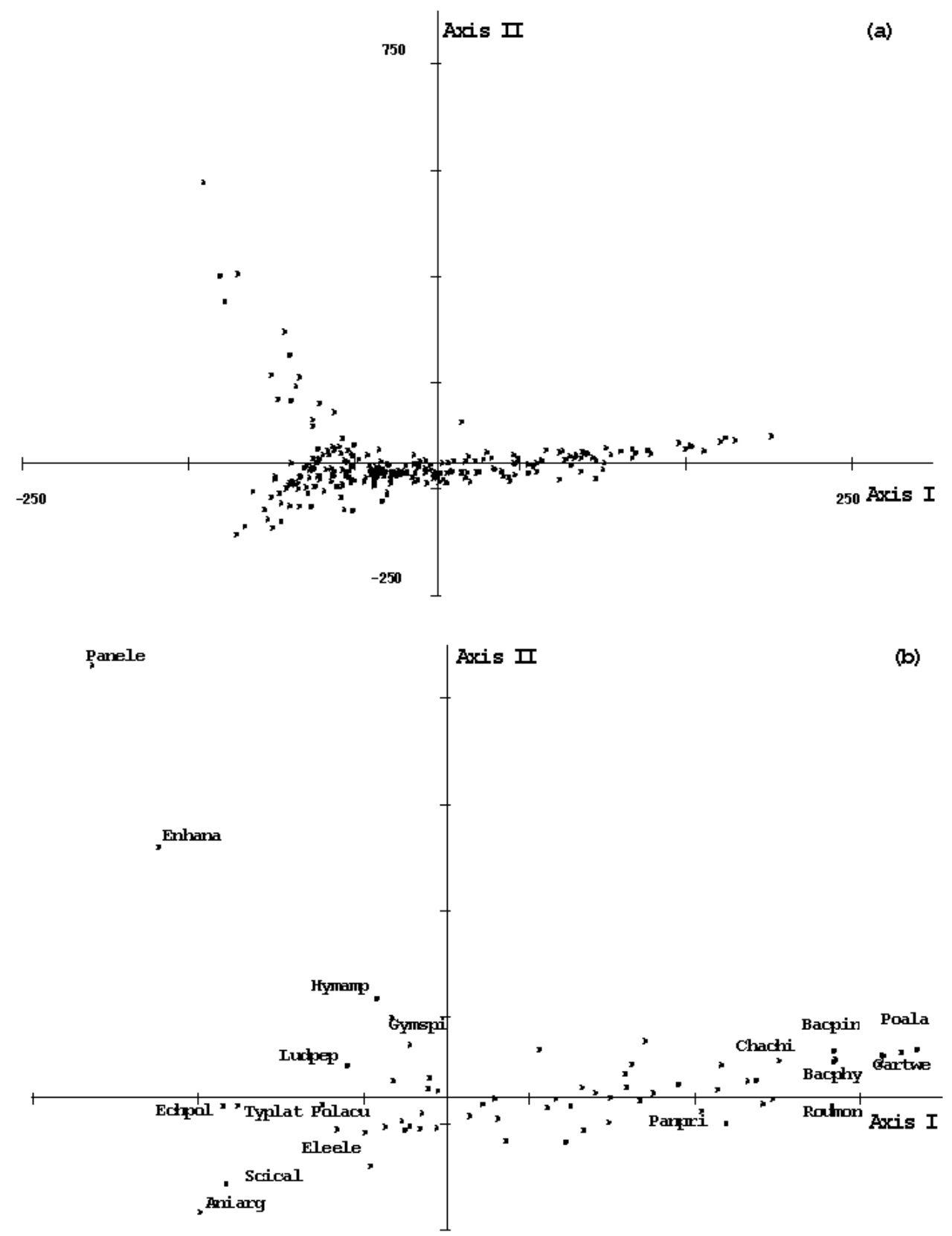

Figure 4. Scatter diagram of samples (a) and species (b) in the plane of Axes I and II of reciprocal averaging ordination. Abbreviations: Aniarg, Aniseia argentina; Bacphy, Baccharis phyteumoides, Bacpin, Baccharis pingraea; Chachi, Chaetotropis chilensis; Cartwe, Carex tweediana; Echpol, Echinochloa polystachya; Eleele, Eleocharis elegans; Enhana, Enhydra anagallis; Gymspi, Gymnocoronis spilanthoides; Hymamp, Hymenachne amplexicaulis; Ludpep, Ludwigia peploides; Panele, Panicum elephantipes; Panpri, Panicum prionitis; Poalan, Poa lanigera, Polacu, Polygonum acuminatum; Roumon, Roulinia montevidensis; Scical, Scirpus californicus; Typlat, Typha latifolia. 


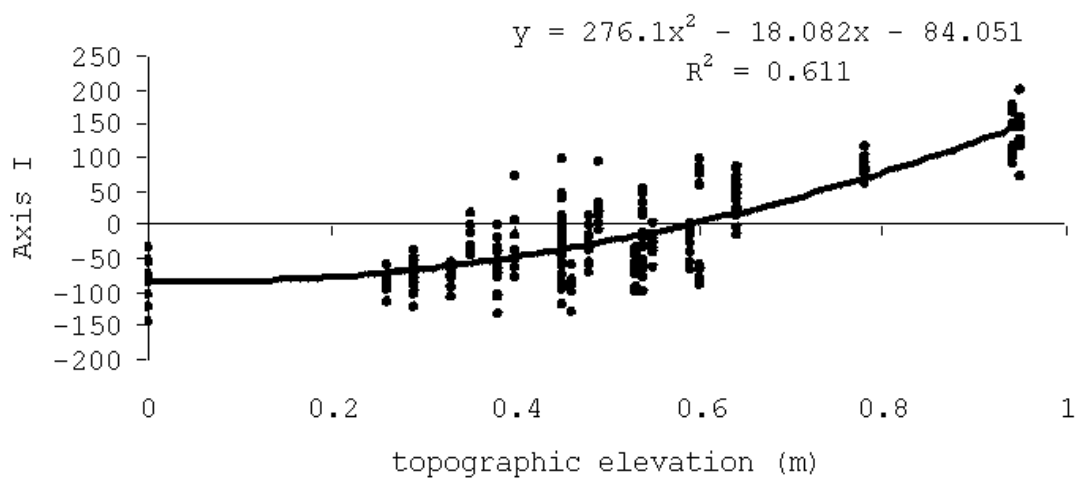

Figure 5. Quadratic regression between relative topographic elevation and sample units scores on Axis I of reciprocal averaging ordination.
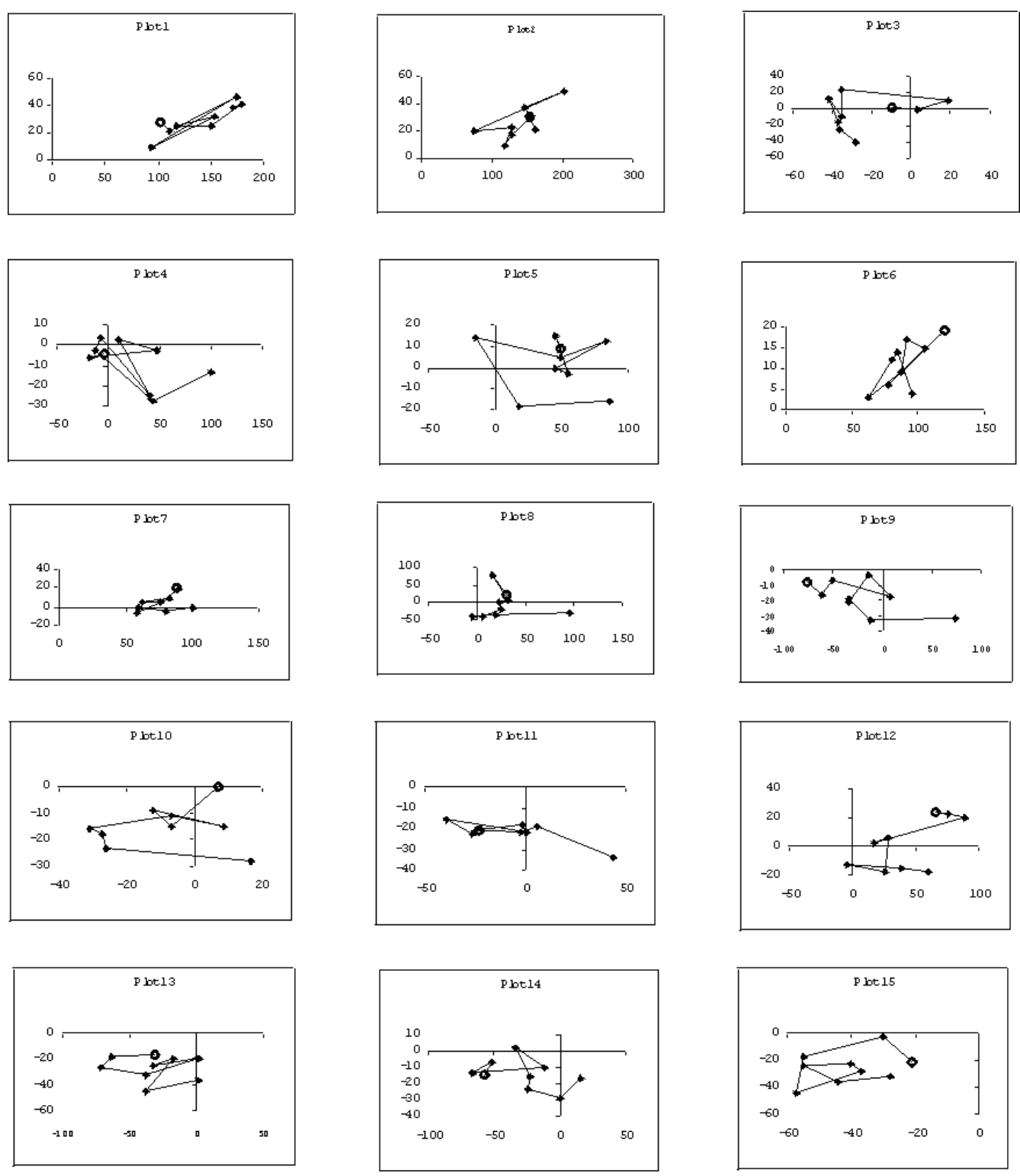

Figure 6. Sample trajectory of plots: a) 1 to 15 (above) and b) 16 to 30 (opposite page). The biggest black dot indicates the first year. 
1988 fire and subsequent flood) has gone through, but the modelling environmental factor still remains the same.

The absence of any identifiable tendencies in the temporal trajectories for each plot makes obvious the lack of important changes of hygrophilous species for mesophilous ones, or the encroaching of hygrophilous communities by the mesophilous ones of the higher part of the elevation gradient, as it should be expected if there was a successional change. The sample units that appeared separated from the rest contained populations of the rooted floating grass $P$. elephantipes, which resulted to be relevant only during the first year after the extraordinary flood, or in the fourth year in plot 29 after the fire and followed by a major flood. Similar temporal trajectories have been shown for other floodable environments in
Europe and USA (Bornette and Amoros 1991, 1996, Battaglia et al. 1995, in the upper end of the gradient). This pattern of temporal response, non linear and erratic rather than fluctuating, seems to have more relationship with a stable vegetation stage than with the successional stages of a community (Orlóci 1993). Nevertheless, and despite that the present results do not allow for a successional scenario, the lower end of the gradient here studied also showed the greater compositional changes in relative terms, though never as high as those of Battaglia et al. (1995).

Temporal trajectories of most plots indicate that the vegetation of each plot is relatively stable, which is supported by the fact that $46.6 \%$ of them (Table 1 ) have similar vegetation in the first year and at the end of the ana-
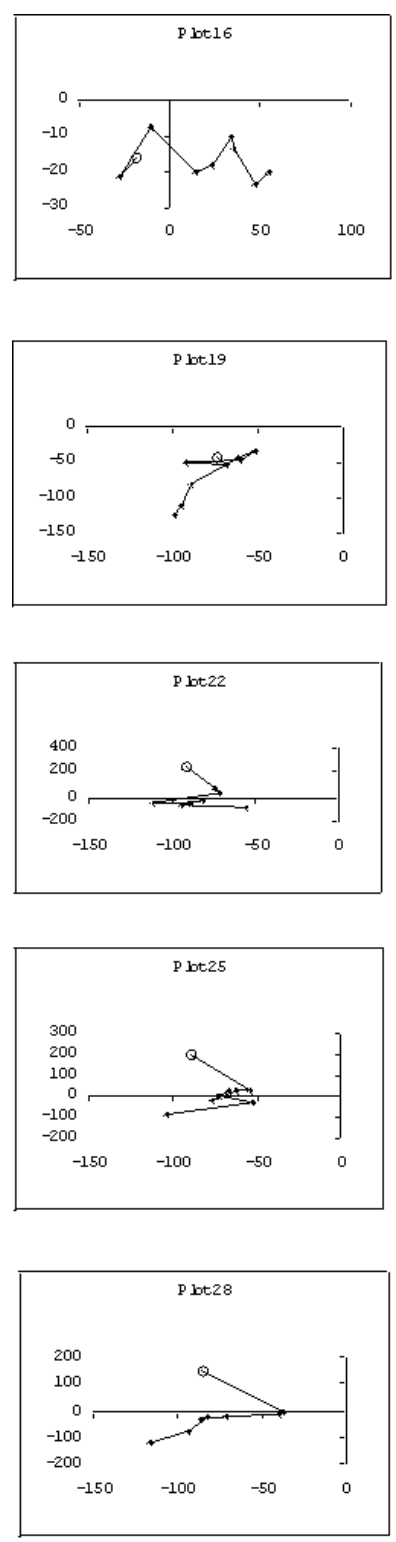
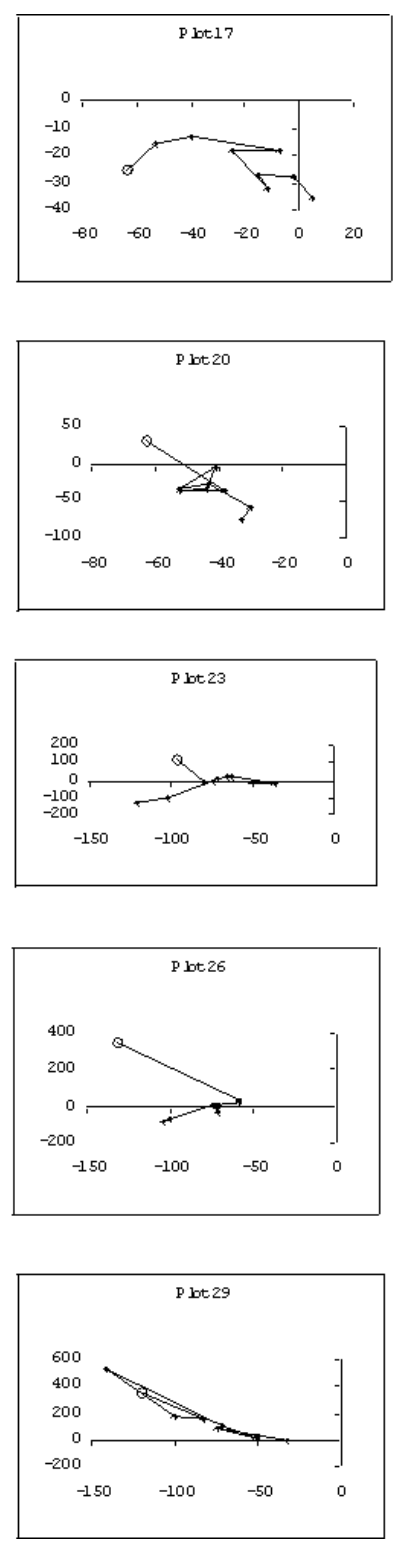
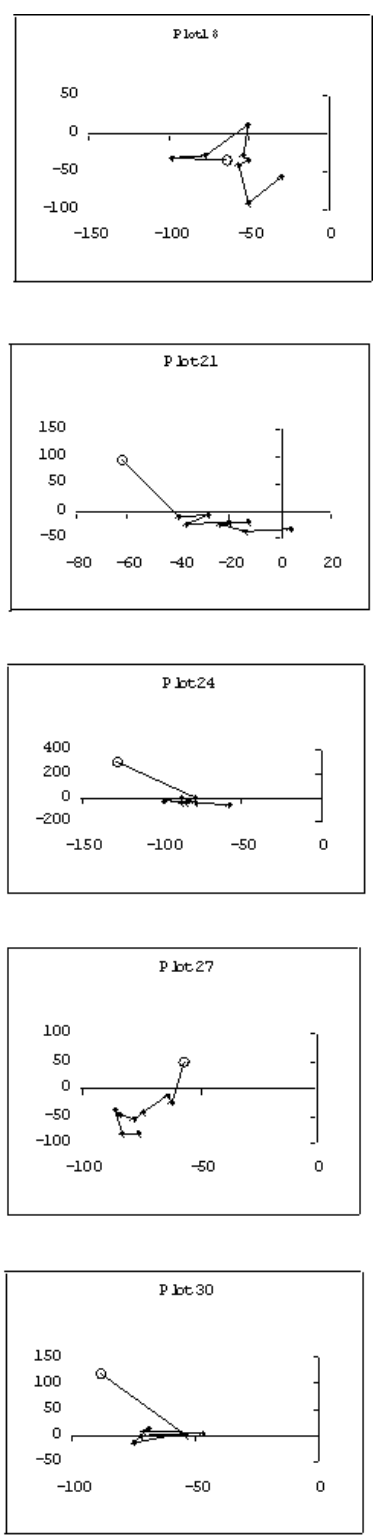
Figure 7. Annual diversity (a), floristic richness (b) and equitability (c) averages and standard deviations.

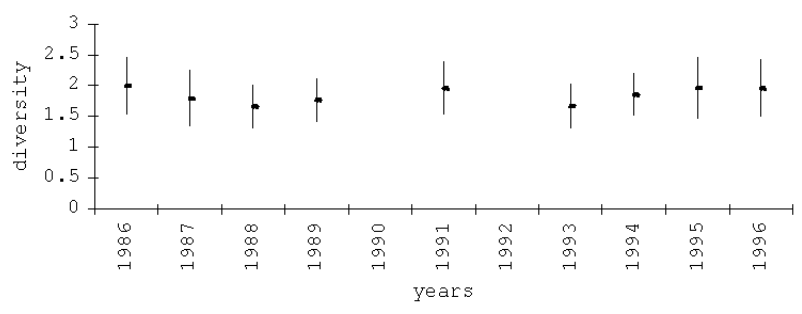

(b)
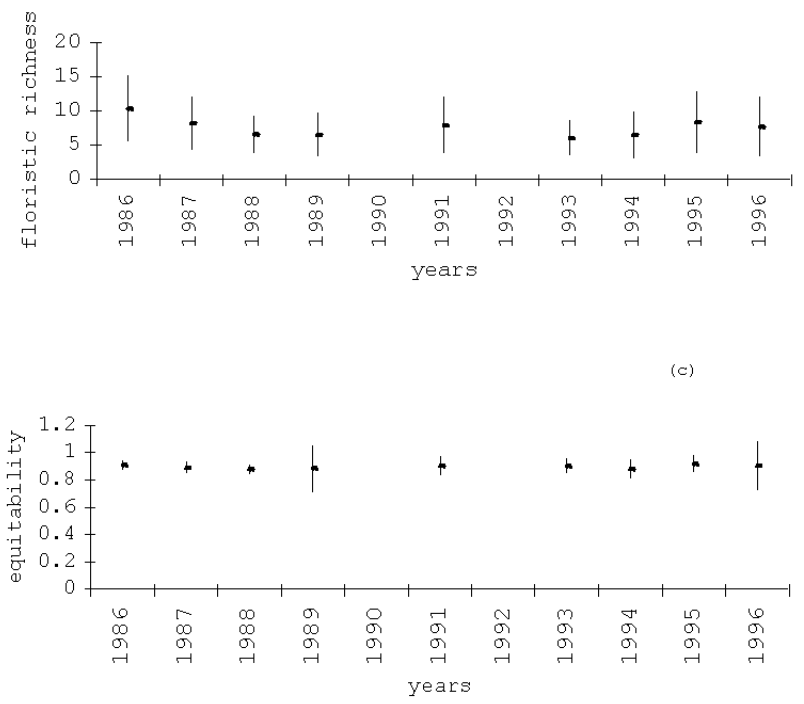

lysed period and no important community replacements have been observed. There is, however, a synchronous and somewhat relevant change from 1989 onwards (Table 1c), caused by a marked double disturbance (the 1988 fire and subsequent early flood). The complete destruction of the vegetation is an obviously radical change for a community; however, it is notable that the first plant communities to appear immediately after the 1983 catastrophic flood have been evaluated as essentially similar to the previous ones (Franceschi and Prado 1989) and also shown in the present analysis. Even the abundance and dominance in patches of the rooted floating grasses was shortlived, so that the $P$. elephantipes communities lasted just only one year and the E. polystachya up to three, until the moment in which double subsequent disturbances allowed for an ephemeral recovery of $P$. elephantipes only in plot 29 and the second species became rare up to its complete disappearance.

The fast recovery of the vegetation in the flooding valley of the Paraná River, despite its complete destruction in cycles, should be attributed in all likelihood to the availability of propagules on the ground (the "propagule stage" of Noble and Slatyer 1980) and to the clonal habit of the dominant species. The dominant species should be perennials with some trait for asexual reproduction, as predicted by Bazzaz (1996); indeed, P. prionitis, Thalia geniculata, Eleocharis nodulosa, E. elegans, Scirpus californicus, Hymenachne amplexicaulis, Solanum glaucophyllum, have subterranean rhizomes capable of resprouting and they are doubtless clonal populations. Possibly the same is true for $P$. elephantipes, $P$. acuminatum and Alternanthera philoxeroides, as they have easily rooting stems (personal observation). This feature of the dominant species grants considerable resilience to their communities, as in this way they pre-empt the areas to be occupied. Some populations can regenerate from the remaining propagules or from those arriving to the site by means of "embalsados" or "camalotales" (floating masses of aquatic plants carried over by the River Paraná overflowing waters during flood; Tur 1972). Thus, species such as P. elephantipes, L. peploides, Polygonum spp. or A. philoxeroides can develop successfully from the propagules that are left behind by the fast drawdown waters. Some species could not only regenerate vegetatively but also they could probably reinstall themselves through the soil seed bank.

The importance of disturbance for diversity has been widely demonstrated (van der Maarel 1993), and the peaks of maximum diversity and floristic richness associated to rather infrequent disturbances are well-known 
(Denslow 1985, van der Maarel 1993), which has been noted for the vegetation of this river as well (Lewis et al. 1987, Franceschi and Lewis 1991). An almost unchanging floristic richness and equitability together with no important changes of one type of species for other, indicate that vegetation is very stable, and do not suggest a successional process.

It is interesting to note that the level of vegetation disturbance of the extraordinary floods of the River Paraná seems to be much more important than the Caribbean tropical hurricanes. The latter result mainly in pronounced defoliation of the trees, and mortality, usually of about $7 \%$ (Walker 1991), seldom goes beyond $13 \%$ of the trees involved (Tanner et al. 1991). Because of that and the rapid recovery of trees, it has even been suggested that hurricanes are not catastrophic events at all (Brokaw and Walker 1991). Furthermore, the fires that frequently follow in the wake of hurricanes may be more important than direct hurricane damage (Whigham et al. 1991). On the contrary, the kind of catastrophe dealt with here causes in the River Paraná many more plant casualties.

Therefore, it can be concluded that the herbaceous vegetation of this area, spatially ordered following a humidity gradient associated to a topographic elevation gradient, is very resilient in the face of major or even catastrophic disturbance, and that after it all communities will quickly recover through a process of "regeneration succession" (van der Maarel 1988). This vegetation reacts to strong, infrequent disturbances in phase, by means of conspicuous but brief changes which quickly disappear as a result of the notable resilience of its communities. This also clearly indicates the great stability of these subtropical communities, thus supporting van der Maarel's (1993) contention: "Disturbance FOR Stability", widening its application to these subtropical, riparian communities of the River Plate basin.

Acknowledgements: Financial support from CONICET and CIUNR is gratefully acknowledged. The authors are indebted to J. Fernández, E. Pire, M. Zinny, E. Brnich, I. Barberis and E. Acosta for help with field work, and to the anonymous reviewers for their comments.

\section{References}

Austin, M.P. 1977. Use of ordination and other multivariate descriptive methods to study succession. Vegetatio $35: 165-175$.

Austin, M.P. 1981. Permanent quadrats: An interfase for theory and practice. Vegetatio 46:1-10.

Bakker, J.P., H. Olff, J.H. Willems and M. Zobel. 1996. Why do we need permanent plots in the study of long-term vegetation dynamics?. J. Veg. Sci. 7:147:156.

Battaglia, L.L., J.R. Keough and D.W. Pritchett. 1995. Early secondary succession in a southeastern U.S. alluvial floodplain. $J$. Veg. Sci. 6:769-776.
Bazzaz, F.A. 1996. Plants in Changing Environments. Cambridge University Press, Cambridge.

Bergeron, Y., O. Engelmark, B. Harvey, H. Morin and L. Sirois (eds). 1998. Key issues in disturbance dynamics in boreal forests. $J$. Veg. Sci. 9:463-610.

Bó, R.F. and A.I. Malvárez, 1999. Las inundaciones y la biodiversidad en humedales. Un análisis del efecto de eventos extremos sobre la fauna silvestre. In: Malvárez, A.I. (ed) Tópicos sobre humedales subtropicales y templados de Sudamérica. UNESCO. Montevideo.

Bonetto, A.A. 1975. Hydrologic regime of the Paraná River and its influence on ecosystems. In: A.D. Hasler (ed), Coupling of Land and Water Systems. Springer-Verlag, New York, pp. 175-197.

Bornette, G. and C. Amoros. 1991. Aquatic vegetation and hydrology of a braided river floodplain. J. Veg. Sci. 2:497-512.

Bornette, G. and C. Amoros. 1996. Disturbances regimes and vegetation dynamics: role of floods in riverine wetlands. J. Veg. Sci. 7:615-622.

Braun-Blanquet, J. 1979. Fitosociología. H. Blume Ediciones, Madrid.

Brokaw, N. and L.R. Walker. 1991. Summary of the effects of Caribbean hurricanes on vegetation. Biotropica 23:442-447.

Burkart, A. 1957. Ojeada sinóptica sobre la vegetación del delta del río Paraná. Darwiniana 11:457-561.

Burkart, A. 1969, 1974, 1979, 1987. Flora ilustrada de Entre Ríos. Colección Científica del INTA, Buenos Aires.

Cabrera, A. 1963, 1965a,b, 1967, 1968, 1970. Flora de la Provincia de Buenos Aires. Colección Científica del INTA, Buenos Aires.

Cabrera, A. 1976. Regiones Fitogeográficas Argentinas. ACME Agency, Buenos Aires.

Connell, J.H. and W.P. Sousa. 1983. On the evidence needed to judge ecological stability or persistence. Amer. Nat. 121:789-824.

Dansereau, P. 1957. Biogeography. Ronald Press, New York.

Delcourt, H.R., P.A. Delcourt and T. Webb III. 1983. Dynamic plant ecology: The spectrum of vegetational change in space and time. Quat. Sci. Rev. 1:153-175.

Denslow, J. 1985. Disturbance-mediated coexistence of species. In: S.T.A. Pickett and P. White (eds), The Ecology of Natural Disturbance and Patch Dynamics. Academic Press, Orlando, pp. 307-323.

Engelmark, O., R. Bradshaw and Y. Bergeron (eds). 1993. Disturbance dynamics in boreal forest. J. Veg. Sci. 3:729-832.

Falinski, J.B. 1988. Succession, regeneration and fluctuation in the Bialowieza Forest (NE Poland). Vegetatio 77:115-128.

Franceschi, E.A. and J.P. Lewis. 1979. Notas sobre la vegetación del valle santafesino del río Paraná (República Argentina). Ecosur 6:55-82.

Franceschi, E.A. and J.P. Lewis. 1991. Early stages in the Paraná river tall grassland recovery after an extraordinary flood. Coenoses 6:47-52.

Franceschi, E.A. and D.E. Prado. 1989. Distribution of herbaceous communities of the river Paraná valley along an elevation gradient after a catastrophic flood. Coenoses 4:47-53.

Franceschi, E.F., D.E. Prado and J.P. Lewis. 1985. Comunidades vegetales y mapa de vegetación de la Reserva El Rico e islas aledańas (Provincia de Santa Fe, Rep. Argentina). Servicio de Publicaciones UNR, Rosario.

Gauch, H.G. 1982. Multivariate Analysis in Community Ecology. Cambridge University Press, New York. 
Glenn-Lewin, D.C. and E. van der Maarel. 1992. Patterns and processes in vegetation dynamics. In: D.C. Glenn-Lewin, R.K. Peet and T.T. Veblen (eds), Plant Succession. Theory and Prediction. Chapman and Hall, London, pp. 11-59.

Grime, J.P. 1979. Plant Strategies and Vegetation Processes. J. Wiley and Sons, Chichester.

Hollander, M. and Wolfe, D.A. 1973. Nonparametric Statistical Methods. J. Wiley and Sons, New York.

Iriondo, M.H. 1972. Mapa geomorfológico de la llanura aluvial del río Paraná desde Helvecia hasta San Nicolás. República Argentina. Rev. Asoc. Geol. Arg. 27:155-160.

Iriondo, M.H.and E.C. Drago. 1972. Descripción cuantitativa de dos unidades geomorfológicas de la llanura aluvial del Paraná Medio. República Argentina. Rev. Asoc. Geol. Arg. 27:145-154.

Lewis, J.P., E.A. Franceschi and D.E. Prado. 1987. Effects of extraordinary floods on the dynamics of tall grasslands of the river Paraná valley. Phytocoenologia 15:235-251.

Lewis, J.P. and E.A. Franceschi. 1979. Notas sobre la dinámica de la vegetación del valle del Rio Paraná. Ecosur 6:145-163.

McCune, B. and M.J. Mefford. 1999. PC-ORD. Multivariate Analysis of Ecological Data, Version 4. MjM Software Design, Gleneden Beach, Oregon.

Morello, J. 1949. Las comunidades vegetales de las islas cercanas al puerto de Rosario. Tesis $\mathrm{N}^{\circ} 133$, Museo de Ciencias Naturales de La Plata.

Noble, I.R. and R.O. Slatyer. 1980. The use of vital attributes to predict successional changes in plant communities subject to recurrent disturbances. Vegetatio 43:5-21.

Orlóci, L. 1993. Conjectures and scenarios in recovery study. Coenoses 8:141-148.

Philipi, T.E, P.M. Dixon and B.E. Taylor. 1998. Detecting trends in species composition. Ecological Applications 8:300-308.

Pickett, S.T.A. and P. White. 1985. The Ecology of Natural Disturbance and Patch Dynamics. Academic Press, Orlando.
Prado, D.E. and P.E. Gibbs. 1993. Patterns of species distributions in the dry seasonal forests of South America. Ann. Missouri Bot. Gard. 80:902-927.

Siegel, S. 1980. Estadística no paramétrica aplicada a las ciencias de la conducta. Ed. Trillas. Mexico.

Sousa, W.P. 1984. The role of disturbance in natural communities. Annu. Rev. Ecol. Syst. 15:353-391.

Tanner, E., V. Kapos and J.R. Healey. 1991. Hurricane effects on forest ecosystems in the Caribbean. Biotropica 23:513-521.

Tilman, D. 1985. The resource ratio hypothesis of succession. Am. Nat. 125:827-852.

Tur, N.M. 1972. Embalsados y camalotales de la región isleńa del Paraná medio. Darwiniana 17:397-407.

van der Maarel, E. 1988. Vegetation dynamics: patterns in time and space. Vegetatio 77:7-19.

van der Maarel, E. 1993. Some remarks on disturbance and its relations to diversity and stability. J. Veg. Sci. 4:733-736.

Veblen, T.T. 1992. Regeneration dynamics. In: D.C. Glenn-Lewin, R.K. Peet and T.T. Veblen (eds), Plant Succession. Theory and Prediction. Chapman and Hall, London, pp.152-187.

Walker, L.R. 1991. Tree damage and recovery from Hurricane Hugo in Luquillo Experimental Forest, Puerto Rico. Biotropica 23:379-385.

Whigham, D.F., I Olmsted, E. Cabrera Cano and M.E. Harmon. 1991. The impact of Hurricane Gilbert on trees, litterfall, and woody debris in a dry tropical forest in the northeastern Yucatan Peninsula. Biotropica 23:434-441.

Westman, W.E. 1978. Meassuring the inertia and resilience of ecosystems. BioScience 28:705-710.

Westman, W.E. and O'Leary, J.F. 1986. Measures of resilience: the response of coastal sage scrub to fire. Vegetatio 65:179-189.

Wildi, O. and L. Orlóci 1990. Numerical Exploration of Community Patterns. SPB Academic Publishing bv, The Hague. 